\title{
The research of higher education management in the process of popularization of Higher Education
}

\author{
Tao Xu \\ Pass College \\ Chongqing Technology and Business University \\ Chongqing,China
}

\begin{abstract}
- popularization of higher education has become a hot issue of Chinese higher education. But along with the popularization process, how can the higher education management reform, lacks in-depth research. Generated from several aspects of this theory, the meaning of popularization of higher education, Popular Higher Education and management was discussed: With the popularization of higher education, higher education management concept form, and content will be changed. These changes are dramatic, sustained and inevitable. After entering the 21st century, the biggest feature of Chinese higher education reform will be how to further change of higher education management system after entering the popular stage.
\end{abstract}

Keywords- higher education; popularity; Education Management

\section{INTRODUCTION}

"Popularization of higher education" and "mass higher education" has only one word different, but contains different meanings. "Change" is a dynamic term; it means transform from one state to another state. "Higher Education Popularization" means that the change from a few people can enjoy higher education original to the majority of people can enjoy higher education, highlighting the shift from the elite to the public during the process from quantitative to qualitative change. The concept of "mass higher education" comes from the 18th century in Europe, where carry out the "public basic education." in the Early 20th century, more and more high school graduates entered universities, in the face of the dramatic increase of enrollment has triggered a series of issues by Martin Trow (MartinTrow) in 1962 in the "democratization of American higher education." a paper first proposed the concept of "mass higher education", and in 1970 proposed the concept of "universal access", and thus produced a "Higher Education Popularization" stage theory. In earlier

studies, most people with a "mass higher education" as a synonym for "popularization of higher education", with the "popular" and "universal" phase of the transition from elite higher education stage, people think the concept of "Higher Education Popularization" can better reveal the change from meet the needs of elite to meet the public demand. Then, the concept of "Higher Education Popularization" is widely used. The "mass higher education" is used to indicate the status and characteristics of "Higher Education Popularization" stage, and contrast with the concept of "elite higher education" ,is also in the system of "popularization of higher education" 's two systems.

\section{THE LOCATION PROBLEM IN UNIVERSITIES OF OUR COUNTRY}

While affirming the achievements of college orientation we should also be aware that with the increasing complexity of the structure of higher education, universities categories and levels of increasing there are still some outstanding issues in positioning our country's colleges.

\section{A. The missing of the status in the dominant of Positioning}

With the advent of social and economic development as well as the popular stage of higher education, diverse social demand for talent and the changing needs the University respond promptly and adjust their positioning direction. Because there is a big difference between the development of their respective historical background and the location and other factors, of which the district, school infrastructure and conditions, the strength and the level of educational institutions of higher learning, and only a deep understanding of their inherent uniqueness, based on colleges and universities in order to achieve a reasonable position. In this sense, the positioning of the main institutions of higher education is colleges and universities, the government should not only be guided too much intervention. But our government institutions of higher learning has obvious characteristics: funds mainly from government funding, activities and services depend on the government, institutional settings executive level administrative personnel undertaking the preparation of a high degree of selfcontained closed. Positioning is basically not an internal or universities and colleges based government, the market consultation on development decisions made, but positioning from the government. the government issued the enrollment of institutions of higher education, and decided to set up professional courses. Schools in positioning based on the will of the government better improve the school's own evaluation of worth and market feedback, resulting in lacking of the dominant position of the university. For example, the establishment of 985, consolidation among 
colleges and universities, is government-led restructuring of higher education layout; more reflected the will of the government, rather than proactive awareness of universities. Universities lost "ownership" of the identity of the school principal, there is no power and the pressure to take care of the issue of whether a reasonable college orientation, positioning in this time has become a passive position.

\section{B. the contradiction between the increasing number of students and ensure the quality}

Implementation of higher education, so that an increase in the number of accept to higher education, decline in the quality of students and colleges teaching conditions difficult to adapt to sudden expansion of the scale of education needs. If the teaching process was not strict, can not be really "strict out", is bound to affect the quality of education. This requires us to study on the one hand how to improve the quality of education, on the other hand we need to update the education quality. In Elite education stage, university study is considered the master of profound knowledge of the local culture of the academic requirements above all else, with the emphasis on academic criteria to measure the quality of education in universities. The popular education emphasizes social adaptability of personnel training, advocated graduates knowledge, the ability to meet the needs of local economic development, whether it is a measure of the quality of education standards. In popular education should establish multi-stage evaluation of educational quality standards and systems, neither exclude Quality elite education, evaluation criteria should also be adapted to popular education model.

\section{OPTIMIZATION OF HIGHER EDUCATION QUALITY ASSURANCE MECHANISMS OF POLICY}

On the concept of policy formulation and implementation should fully respect the autonomy of academic colleges, school autonomy. Under the guidance of the government's macro-premise, you can build the organization responsible for the quality of higher education in accordance with the actual situation. This body is mainly within the university on behalf of the Government to strengthen the organization's external quality audit supervision and guidance, which focuses on quality assurance oversight mechanism universities rationality and effectiveness. And in the case of external quality audits University organizations function fails, the timely development of internal university quality control standards. It is worth mentioning that, within the university external quality audit organizations conducting specific review, you should pay attention to attract students to participate, and also regularly organized satisfaction survey of college students to follow the British national. Second, the development of information portal supervises the construction of university policy. Emphasize the potential willingness of individuals to accept selective higher education, participation. Our country can refer to the United Kingdom, to encourage university students release online for future reference information, including teaching time, accommodation costs, and the employment rate and indexed according to the course starting salaries of graduates. In the Internet age, more and more potential college students tend to regard the quality of teaching at the University of Online Search, the teacher-related professional quality, student evaluation of courses and other information of their choice as an important reference for college. Such measures will undoubtedly increase competition among colleges and universities to promote the pursuit of their own to further improve quality.

\section{CHINESE REFORMS OF POPULARIZATION AND MANAGEMENT SYSTEM OF HIGHER EDUCATION}

Since the 1990s, Chinese higher education in the social and educational needs and the individual needs the dual role, began to shift to the popular stage. After nearly eight years of sustained development, it accelerates the development of higher education for the whole country to form a consensus. However, due to the inertia of the old system of China, Chinese higher education in order to achieve popularity in the early 2000s, following changes should be carried out in the management system of higher education. Further open to the outside the higher education market, break the monopoly of the state sector of higher education market situation. Substantive reform of higher education is from the "stateowned Municipal Government" in a single form, the development of the school system for a variety of ownership. First, it is "the state-owned public." Previous schools belong to the state or local governments by the government schools, "regardless of the political school" to "state-owned public", "separate from government schools." Universities are involved in the education department council. The second is "state-owned private." Certain by the state or local government contractor colleges transferred to an independent legal entity composed by members of the community to contractor operations. The third is "of the people private." Independent schools raise funds by social forces. Fourth, it is "a joint venture jointly." Allow and encourage foreign universities and other social organizations that meet the criteria to set up regular school college, community college, and professional training schools. Encourage world-class universities and world-class Chinese class university organized professional, college and even organized a worldclass university.

\section{ESTABLISH COST COMPENSATION MECHANISM, MAKE FULL USE OF FINANCIAL INSTRUMENTS TO PROMOTE THE DEVELOPMENT OF HIGHER EDUCATION}

As a concrete measure to establish higher bank, or in the national development bank set up a special development fund higher education, paid use. Source Higher Education Development Fund relies on government funds and it should be based single channel to use financial instruments to diversify channels based transformation. Higher Education Development Fund comes from a variety of sources: First, the government or state-owned banks Higher Education Development Fund for capital, if necessary, we may issue special long-term bonds, to allow holders of corporate bodies; the second is the establishment of private higher education development fund to encourage residents part of the deposit 
into a future investment in education; the third is hard to win international bank loans for higher education organization development; Fourth, overseas Chinese and international education organizations contribute funds; fifth is social groups of donor funding; sixth is absorbed and universities deposits teachers and personal savings. Corresponding to this, universities should develop a reasonable fee, with the cost of compensation to make up for inadequate investment in colleges and universities.

\section{CHINESE HIGHER EDUCATIONS BECOMING POPULAR IS THE NEED OF CULTURAL DEVELOPMENT}

University's existence of time is longer than any other form, government, any tradition, legal changes and scientific thinking, because it needs to meet the eternal people in all sorts of people to create, and nothing is more than the long engulfed University all the test of time. "Cultural characteristics inherent in the University has been functioning mechanisms underlying the development of the University, heritage and discovery has profound knowledge of university life, there is the power source from generation to generation. University is relying on the cultural, university life has evergreen; culture carried on into college, culture in more a long history is more widely spread. Under the circumstances continue to enrich the material, social and cultural needs the increasingly urgent necessity, culture is within the broader context of heritage; at a deeper level in the mining, more diversified cultural development to some extent depend on the great development of the university. In short, both the cultural needs of the community or culture further their own developments are inseparable from the Open University, and the popular needs of higher education.

At present, China's Higher Education Popularization existing differences should have been by the popularization of science to determine the evolution of how popular the speed and in what way to achieve popularity. University disagreement is on whether the school has evolved from enrollment to what extent enrollment. From a variety of publications, we can see that some people think that popularity is related to the economic development of the country as well as comprehensive position in the world, it should be against all odds, early realize popularity; another part that under the banner of the popular university has overload, affecting the quality of higher education, a college degree has produced with bad money drives out good money, "Gresham's Law", diploma devaluation, China should adhere to the quality-based, slow down the speed of popularity, and some even consider it popularization of higher education and need to revisit this issue. Differences in both countries in the period of rapid development of higher education are different levels of existence; the performance was relatively strong in the country. Differences with differences of enrollment for higher education massification seem the same, but in fact they are two different concepts. Popularization of higher education has never asked that the only way through university enrollment to achieve popularity, it does not require the University of popularity, because in popularity in the process, we have to understand the popular theory is unscientific, incomplete, in the application of theoretical guidance the practice, universities emerged problems in following several aspects, resulting wrong attitude in the community in the implementation of popularization of higher education policy.

\section{CONCLUSIONS}

Popularization of higher education is a process, in this process, there will be all kinds of contradictions and conflicts, and this conflict is inevitable, unavoidable. In the early $21 \mathrm{st}$ century, China is in the stage of higher education, the number of large-scale development, quality decline, there was rise of private colleges, tuition rose sharply, and they are the inevitable outcome of this process. After the popularization of higher education, this change will continue, but the emergence of new problems will be different from now.

\section{References}

[1] Shi Chao. towards popularization of higher education in the process of higher education management $[\mathrm{J}]$ Shandong Agricultural University (Social Sciences), 2000,04: 1-4.

[2] Wu Daguang. basic features Popularization of Higher Education and the responsibility of the government [J] Education Research, 2002,03: 24-27.

[3] Li Guoli. transform the popular Chinese development model of higher education [J] Journal of Education, 2014,01: 17-27.

[4] Sun Yujie. Excessive interpretation popularization of higher education theory and reflection [J] Jiangsu Higher Education, 2007,06: 9-12.

[5] Wu Daguang. popularization of higher education and the concept of analytic theory connotation [J] Education Research, 2004,09: 20-24.

[6] Lan Jian. international experience Popularization of Higher Education and Its Implications for China $[\mathrm{J}]$ Higher Education Exploration, 2006,01: 4-7.

[7] Han Feizhou. The majority of people in higher education popularization "China model" theory \& practice [J] China Higher Education Research, 2006,06: 29-31.

[8] Ji Baocheng. Popularization of Higher Education Challenges and countermeasures [J] Higher Education Research, 2006,07: 1-10.

[9] Xu Xudong. Mass Education locate university research [J] Higher Education Exploration, 2003,01: 31-33 + 47 . 